\title{
Sponge Diversity at Pecaron Bay Situbondo Based on Macroscopic and Microscopic Observation
}

\author{
Edwin Setiawan ${ }^{1}$, Awik Pudji Diah Nurhayati ${ }^{1}$, and Farid Kamal Muzaki ${ }^{2}$
}

\begin{abstract}
The sponge species diversity recruited insitu macroscopic observation i.e, underwater photograph for sponges species diversity and spicula microscopic examination for sponges order group specimens have been conducted at Pecaron Bay Situbondo. Seventeen sponges species have been identified out of twenty species. The microscopic examination showed that the Diactinal oxea types were dominant in our 13 samples whereas the monoactinal oxea and style were represented only with 7 samples. Moreover, diactinal type of spicula can be used as an order group of sponges species at Pecaron bay Situbondo.
\end{abstract}

Keywords-Sponges species diversity, macroscopic observation, spicules microscopic observation, sponge groups order, Pecaron bay Situbondo.

\section{INTRODUCTION}

$\mathrm{S}$ ponges are the most ancient multicellular animals, having existed for more than 580 million years (Muller et al., 2004). At least 15000 species are classified into the Phylum Porifera, which is divided into three classes, the Hexactinellida, the Demospongiae, and the Calcarea, based on the nature of their mineral skeleton. The methods for identifiying sponges species are varied. The most simple one is morphological spicules identification. Early investigators of sponge biology and taxonomy have already described that spicules and skeletal structures use light microscopic techniques besides insitu morphology character in order to describe sponges diversity and its taxonomy relationship. Therefore, recent developments in sponge spicules research (Sethmann and Worheide 2008), will give an account for early fundamental works sponges taxonomy and diversity.

Pecaron Bay is located at Situbondo East java. This bay has reef structure which consists of Poriferan and Coelenterata. It has been known that poriferan or marine sponge has several roles such as an impacts on substrate (including bioerosion, reef creation, and substrate stabilization, consolidation and regeneration), benthospelagic coupling (including carbon cycling, silicon cycling, oxygen depletion and nitrogen cycling) and associations with other organisms (facilitating primary production, secondary production, provision of microhabitat, enhanced predation protection, survival success, range expansions and camouflage though association with sponges, sponges as a settlement substrate, disrupting near-boundary and reef level flow regimes, sponges as agents of biological disturbance, sponges as releasers of chemicals and sponges as tools for other organisms) (Bell 2008). Since the sponges has play a vital role for marine ecosystem, studying the diversity marine sponge will help to conserve the sponges life and marine ecosystem it selves.

Spicules type the classes taxonomy groups of sponge. Spicules from calcarean groups consist of calcareous spicules with a considerable morphological diversity, in two subclasses Calcinea and Calcaronea with four basic spicules types ie, monoactine, diactiane, triactine and combination (Sethmann and Worheide 2008) whereas, Demospongiae, characterized by monoaxonic or tetraxonic spicules and Hexactinellida, characterized by sincitial organization and hexaradiate spicules. Furthermore two kinds of spicules are produced: megascleres, generally elongate and compose the main architecture of the sponge skeleton, and microscleres, varied in shape and size, with auxiliary functions (Croce et.al, 2004). Moreover, examining the spicule microscopic observation will help the description of sponges diversity at Pecaron bay Situbondo, East java.

\section{MATERIAL AND METHOD}

Sponge samples were taken from Pecaron Bay on the last July 2009 using scuba diving in 5-20 m depth, $500 \mathrm{~m}$ from coast line (Fig. 1). The sponge samples had been photopgraphed underwater to describe the insitu habitat morphology. The samples were preserved by $70 \%$ ethanol solution for spicules identification and morphological identification used as the determination key of Van Soest (1989) and Hooper and Van Soest (2002) whereas for spicules preservation and identification were done by bleaching and acid method for rapid sponge survey (Hooper, 2000). The identification of spicule character is used as the key determination of Andri et al. (2001).

${ }^{1}$ Edwin Setiawan and Awik Pudji Diah Nurhayati are with Department of Zoology Laboratory of Biology, Faculty of Mathematics and Natural Science, Institut Teknologi Sepuluh Nopember, Surabaya, 60111, Indonesia.

${ }^{2}$ Farid Kamal Muzaki is a Graduated Bachelor Student of Biology Department, Faculty of Mathematics and Natural Science, Institut Teknologi Sepuluh Nopember, Surabaya, 60111, Indonesia. 


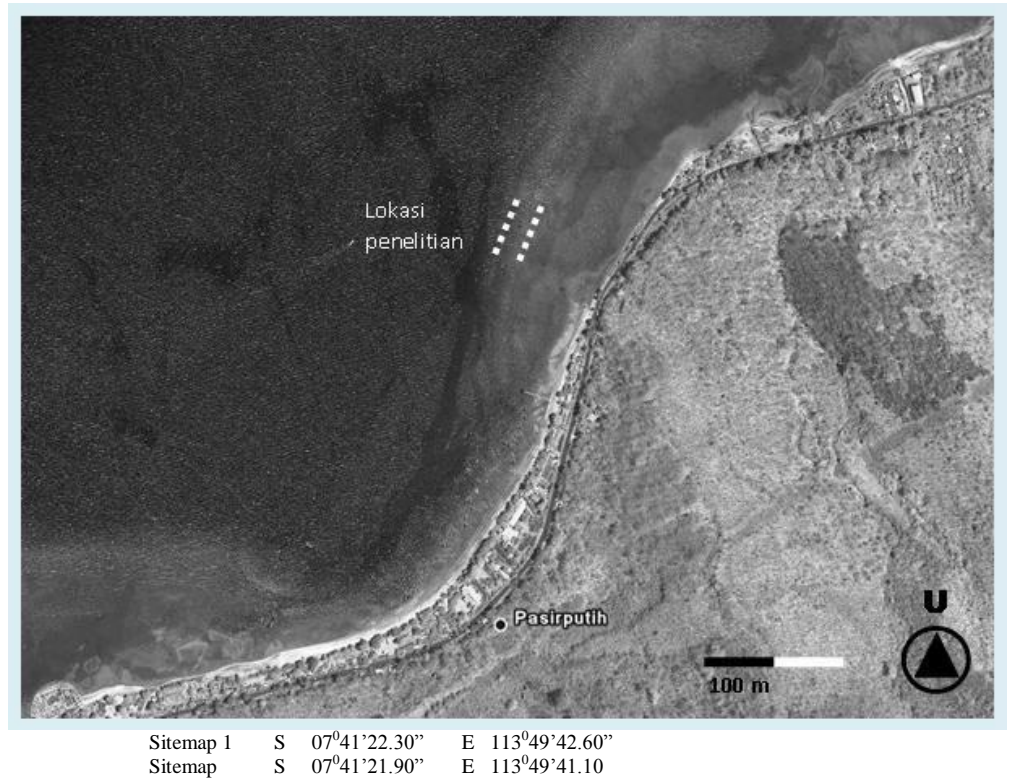

Fig. 1. Research sitemap area of Pecaron bay Pasir Putih Situbondo

\section{RESULT}

Table 1. Underawater, Photograph, Characteristic, Type of SPicula And Species of SpOnge

\begin{tabular}{|c|c|c|c|c|c|}
\hline $\mathrm{Z}$ & $\begin{array}{l}\text { Underwater } \\
\text { Photograph }\end{array}$ & Characteristic & $\begin{array}{l}\text { Spicula Observation } \\
\text { (Scale } 1: 100 \mathrm{X})\end{array}$ & Type Spicula & Species (order) \\
\hline 1 & & $\begin{array}{l}\text { Often giant sized, } \\
\text { red-grey, with } \\
\text { heavily ridged } \\
\text { outer walls, stony } \\
\text { hard }\end{array}$ & & $\begin{array}{c}\text { Diactinal Oxea } \\
\text { (monaxons with } \\
\text { similar ends and } \\
\text { pointed at both ends) } \\
\text { /MDO }\end{array}$ & $\begin{array}{c}\text { Xestospongia } \\
\text { testudinaria } \\
\text { (Haplosclereida) }\end{array}$ \\
\hline 2 & & $\begin{array}{l}\text { Large masses with } \\
\text { reticulate surface, } \\
\text { dark brown to } \\
\text { black, hard but } \\
\text { fibrous }\end{array}$ & & $\begin{array}{c}\text { Diactinal Oxea } \\
\text { (monaxons with } \\
\text { similar ends and } \\
\text { pointed at both ends) } \\
\text { /MDO }\end{array}$ & $\begin{array}{c}\text { Fascaplysinopsis } \\
\text { reticulata } \\
\text { (Dictyoceratida) }\end{array}$ \\
\hline 3 & & $\begin{array}{l}\text { Sharply conulose, } \\
\text { laminated, red- } \\
\text { orange, fragile, } \\
\text { easily torn }\end{array}$ & & $\begin{array}{l}\text { Monactinal Style } \\
\text { (monaxon rounded at } \\
\text { one end and pointed at } \\
\text { the other end with one } \\
\text { end blunt and the other } \\
\text { pointed) /MS }\end{array}$ & Dysidea cinerea \\
\hline 4 & & $\begin{array}{l}\text { Blue-green-grey, } \\
\text { with sharp conules, } \\
\text { resilien }\end{array}$ & 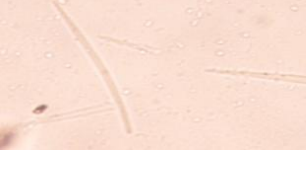 & $\begin{array}{l}\text { (monaxons with } \\
\text { similar ends and } \\
\text { pointed at both ends) } \\
\text { /MDO }\end{array}$ & $\begin{array}{c}\text { Callyspongia } \\
\text { schulzei }\end{array}$ \\
\hline 5 & & $\begin{array}{l}\text { Creeping masses } \\
\text { with variable } \\
\text { presence of low } \\
\text { conules, large } \\
\text { oscules, purple, } \\
\text { spongy-resilient }\end{array}$ & 4 & $\begin{array}{c}\text { Diactinal Oxea } \\
\text { (monaxons with } \\
\text { similar ends and } \\
\text { pointed at both ends) } \\
\text { /MDO }\end{array}$ & Gelliodes pumila \\
\hline
\end{tabular}




\begin{tabular}{|c|c|c|c|c|c|}
\hline $\mathrm{z}$ & $\begin{array}{l}\text { Underwater } \\
\text { Photograph }\end{array}$ & Characteristic & Spicula Observation & Type Spicula & Species (order) \\
\hline 6 & & $\begin{array}{c}\text { Flattened branches, } \\
\text { irregularly conulose, } \\
\text { conules blunt, erect- } \\
\text { creeping, light } \\
\text { brown, very toughly } \\
\text { spongy }\end{array}$ & - & $\begin{array}{c}\text { Monactinal Style } \\
\text { (monaxon rounded at } \\
\text { one end and pointed at } \\
\text { the other end with one } \\
\text { end blunt and the other } \\
\text { pointed) /MS }\end{array}$ & $\begin{array}{c}\text { Dactylospongia } \\
\text { ellegans }\end{array}$ \\
\hline 7 & & $\begin{array}{l}\text { Arm-thick creeping } \\
\text { branches with } \\
\text { thick-walled } \\
\text { oscular chimneys, } \\
\text { red-brown, stony } \\
\text { hard }\end{array}$ & & $\begin{array}{c}\text { Diactinal Oxea } \\
\text { (monaxons with } \\
\text { similar ends and } \\
\text { pointed at both ends) } \\
\text { /MDO }\end{array}$ & $\begin{array}{c}\text { Petrosia } \\
\text { contignata }\end{array}$ \\
\hline 8 & & $\begin{array}{l}\text { Flattened branches, } \\
\text { regularly conulose, } \\
\text { black, toughly } \\
\text { spongy }\end{array}$ & & $\begin{array}{c}\text { Diactinal Oxea } \\
\text { (monaxons with } \\
\text { similar ends and } \\
\text { pointed at both ends) } \\
\text { /MDO }\end{array}$ & Hyrtios erectus \\
\hline 9 & & $\begin{array}{l}\text { Flatly incrusting } \\
\text { with undulating } \\
\text { surface, } \\
\text { ornamented with } \\
\text { network of fine } \\
\text { grooves, mud-grey, } \\
\text { grooves reddish, } \\
\text { spongy }\end{array}$ & & $\begin{array}{c}\text { Diactinal Oxea } \\
\text { (monaxons with } \\
\text { similar ends and } \\
\text { pointed at both ends) } \\
\text { /MDO }\end{array}$ & Liosina arenosa \\
\hline 10 & & $\begin{array}{l}\text { Irregular, with } \\
\text { sharp ridges and } \\
\text { conules, orange-red } \\
\text { with yellow-orange } \\
\text { sheen, rubbery }\end{array}$ & & $\begin{array}{c}\text { Diactinal Oxea } \\
\text { (monaxons with } \\
\text { similar ends and } \\
\text { pointed at both ends) } \\
\text { /MDO }\end{array}$ & Acanthella carter \\
\hline 11 & & $\begin{array}{l}\text { Rounded clathrate- } \\
\text { cavernous masses } \\
\text { consisting of } \\
\text { intertwined } \\
\text { trabeculae } \\
\text { surrounding } \\
\text { rounded cavities, } \\
\text { bright orange }\end{array}$ & & $\begin{array}{l}\text { Monactinal Style } \\
\text { (monaxon rounded at } \\
\text { one end and pointed at } \\
\text { the other end with one } \\
\text { end blunt and the other } \\
\text { pointed) /MS }\end{array}$ & $\begin{array}{c}\text { Acanthella } \\
\text { cavernosa }\end{array}$ \\
\hline 13 & & - & & $\begin{array}{l}\text { Monactinal Strongyle } \\
\text { (monaxon rounded at } \\
\text { one end and pointed at } \\
\text { the other end with } \\
\text { rounded ends)/ MS }\end{array}$ & - \\
\hline 14 & & - & & $\begin{array}{c}\text { Diactinal Oxea } \\
\text { (monaxons with } \\
\text { similar ends and } \\
\text { pointed at both ends) } \\
\text { /MDO }\end{array}$ & - \\
\hline 15 & & $\begin{array}{l}\text { Masses of globular } \\
\text { osculiferous lobes, } \\
\text { orange-brown, } \\
\text { rough to the touch } \\
\text { but compressible; } \\
\text { turns black in } \\
\text { alcohol }\end{array}$ & & $\begin{array}{c}\text { Monactinal Style } \\
\text { (monaxon rounded at } \\
\text { one end and pointed at } \\
\text { the other end with one } \\
\text { end blunt and the other } \\
\text { pointed) /MS }\end{array}$ & $\begin{array}{c}\text { Aaptos aaptos cv } \\
\text { Suberitoides }\end{array}$ \\
\hline 16 & & $\begin{array}{c}\text { Irregular } \\
\text { undulating-conulose } \\
\text { surface, often } \\
\text { covered by } \\
\text { sediment, salmon- } \\
\text { coloured, } \\
\text { compressible }\end{array}$ & & $\begin{array}{c}\text { Monactinal Style } \\
\text { (monaxon rounded at } \\
\text { one end and pointed at } \\
\text { the other end with one } \\
\text { end blunt and the other } \\
\text { pointed)/MS }\end{array}$ & $\begin{array}{l}\text { Clathria } \\
\text { reinwardtii }\end{array}$ \\
\hline
\end{tabular}




\begin{tabular}{|c|c|c|c|c|c|}
\hline $\mathrm{z}$ & $\begin{array}{l}\text { Underwater } \\
\text { Photograph }\end{array}$ & Characteristic & Spicula Observation & Type Spicula & Species (order) \\
\hline 17 & & $\begin{array}{l}\text { Cups or fans, thin- } \\
\text { walled, grey, } \\
\text { regularly spaced } \\
\text { star-shaped oscules } \\
\text { on inside surface, } \\
\text { tough }\end{array}$ & & $\begin{array}{c}\text { Monactinal Style } \\
\text { (monaxon rounded at } \\
\text { one end and pointed at } \\
\text { the other end with one } \\
\text { end blunt and the other } \\
\text { pointed) /MS }\end{array}$ & $\begin{array}{c}\text { Phyllospongia } \\
\text { papyraceae }\end{array}$ \\
\hline 18 & & $\begin{array}{c}\text { Massively } \\
\text { incrusting with } \\
\text { stiff erect branches } \\
\text { or laminations, } \\
\text { smooth, dark } \\
\text { brown, tough- } \\
\text { crumbly }\end{array}$ & & $\begin{array}{l}\text { Diactinal Oxea } \\
\text { (monaxons with } \\
\text { similar ends and } \\
\text { pointed at both ends) } \\
\text { /MDO }\end{array}$ & $\begin{array}{l}\text { Xestospongia } \\
\text { exigua }\end{array}$ \\
\hline 19 & & $\begin{array}{l}\text { Erect slender- } \\
\text { branched bushes, } \\
\text { brownish green-red, } \\
\text { cartilaginous }\end{array}$ & & $\begin{array}{l}\text { Diactinal Oxea } \\
\text { (monaxons with } \\
\text { similar ends and } \\
\text { pointed at both ends) } \\
\text { /MDO }\end{array}$ & $\begin{array}{c}\text { Haliclona } \\
\text { cymaeformis }\end{array}$ \\
\hline 20 & & & & $\begin{array}{c}\text { Diactinal Oxea } \\
\text { (monaxons with } \\
\text { similar ends and } \\
\text { pointed at both ends) } \\
\text { /MDO }\end{array}$ & (Haplosclereida) \\
\hline
\end{tabular}

\section{DISCUSSION}

In order to explore sponge species diversity, sponge spicules are used as a tool for describing sponges morphology and relationship instead of insitu underwater specimen photograph and microscopic tissue observation. Based on spicules microscopic description, the sponges have been grouped into three classes: Demospongiae (mostly sponges with a skeleton, composed of siliceous spicules), Hexactinellida (always Siliceous skeleton) and Calcarea (always calcareous skeleton) (Hooper, 2000). Almost 90\% of sponges species in the world are from Demospongiae Class. In sampling area, $100 \%$ of Demospongian classes after morphology identification based on Van Soest (1989) key determination. Therefore after morphological identification, the spicule observation was performed for species group orders. We could not define the specimen no 13, 14, and 20 since we lost the underwater photograph for 3 specimens. Moreover we just put those three species in order grups based on spicula microscopic examination. After spicules microscopic observation based on key determination of Andri (2001), we grouped 5 orders i.e: Haplosclereida (specimen number $1,4,5,7,18,19)$ which characterized by diactinal spicules, Dictyocertida (specimen number 2, 3, 6, 8, 17), Halichondridae (specimen number 9,10,11) which characterized by styles, oxeas and strongyles, often intergrading into each other with apices ranging from sharply and gradually tapering, to bluntly rounded, often with characteristic stair-stepped appearance, Handromerida (specimen number 12, 15) which characterized by monaxonic megascleres (tylostyles, subtylostyles, oxeas or derivatives spicules, and Poecilosclereida (specimen number 16) which characterized by monoactinal and diactinal siliceous spicules (Hopper and Van Soest, 2002). Order Haplosclereida in our speciment shows diactinal type (monoaxinal with similar ends) Oxea (pointed at both ends) which correspond into Hopper (2002).The species of our haplosclereida refers to specimen 1 Xestospongia testudinaria, specimen 4 Callyspongia schulzei, specimen 5 Gellioides pumila, spacemen 6 Petrosia contignata, specimen 18 Xestopongia exigua, specimen 19 Haliclona cymaeformis and unidentified specimen no 14 and 20. Our specimen in group Dictyoceratida were shown Diactinal oxea on specimen 2 (Fascaplysinopsis reticulata) and specimen 8 Hyrtios erectus whereas monoactinal (monaxon rounded at one end and pointed at the other end) Style (monactinal monaxon with one end blunt and the other pointed) were shown on specimen 3 (Dyidea cinerea), specimen 6, Dactylospongia elegans, and specimen 17 (Phylospongia papiraceae). On Halichondrida specimen, the spicules type Diactinal oxea showed on specimen 9 Liosina arenosa and specimen 10 Achantella carteri whereas the correspond result specimen to Hopper and Van Soest (2002) concerning monoaxon spicules only showed on specimen 11 Acnthella cavernosa. On the Handromerida orders, only specimen no 15, Aaptos aaptos corresponded with monoactinal style type from Hopper and Van Soest (2002) whereas specimen 12, Tethya robusta showed the type of diactinal spicules. Finally on Poecilosclereida group on specimen 16 Clthria reinwardtii showed that spicules type correspond with the result on Hopper and Van Soest (2002) which described that Poecilosclreida group has two type either monoaxinal or diactinal.

Compared to the result of sponge diversity which has been conducted by de Vogt and Clearly 2008 at Jakarta bay, the sponge species at Pecaron bay is less varied. It has happened since the site location of the research in Jakarta were extended into $40 \mathrm{~km}$ from the coastline. On the other hand, our research site location is only $2 \mathrm{~km}$ lenght from the coast line. Inspite of lack species diversity on Pecaron bay, the species most abundancespecies in Jakarta bay which were Aaptos suberitoides (Brønsted, 1934), Clathria (Thalysias) 
reinwardti (Vosmaer, 1880), and Xestospongia testudinaria (Lamarck, 1813) were also presented species at our research site on Pecaron bay.

\section{CONCLUSION}

In the microscopic diversity spicules Diactinal spicules type showed on mostly of our sampling which refers to 13 species whereas the Monoactinal spicules type showed on 7 specimens. Spicules type only can be used as a tool for describing Haplosclereida order which showed the same character of Diactinal oxea type; whereas Dictyoceratida, Halichondrida, Handromerida and Poecilosclereida groups could not be defined by spicules microscopic description character since the type of those groups order were varied between Monoactinal and Diactinal type. Three specimens in Pecaron Bay, ie Aaptos aaptos cv suberitoides, Clathria reinwardi and Xestospongia testudinaria corresponds with the specimen in Jakarta bay

\section{ACKNOWLEDGEMENT}

We would like to acknowledge Dirjen DIKTI (Indonesian National Ministry of Education) which has provided a grant to support this research via Strategic National Fund (Hibah Strategi Nasional) Batch 2.

\section{REFERENCES}

[1] E. Andri, S. Gerbaudo, and M. Testa, 2001, "Quaartenary Siliceous sponge spicules in the western Woodlark basin, Soutwest Pacific (Odp LEG 180)", Proceedings of the Ocean Drilling Program, Scientific Results Vol. 180.

[2] J. J. Bell, 2008, "The functional roles of marine sponges, estuarine", Coastal and Shelf Science 79: 341-353.

[3] Croce et al., "Structural characterizations of Siliceous Spicules from Marine Sponges", Biophysical Journal 86: 526-534.

[4] N. J. Voogt and D. F. R. Cleary, 2008, "An analysis of sponge diversity and distribution at three taxonomic levels in the thousand islandsJakarta bay reef complex, West-Java, Indonesia", Marine Ecology 29 205-215.

[5] J. N. A. Hooper, 2000, http://www.qmuseum.qld.gov.au/ organisation/sections/SessileMarineInvertebrates/index.asp.

[6] J. N. A. Hooper and R. M. W. Van Soest, 2002, "Systema porifera: A guide to the classification of sponges", Kluwer Academic/ Plenum Publishers, New York, pp 169-172, 403-405, 721-723, 831-832, and 1021.

[7] W. Muller et al., 2004, "Bauplan of urmetazoa: basic for genetic complexity of metazoan”, Int. Rev. Cytol: 235, 53-92.

[8] I. Sethmann and G. Worheide, 2008, "Structure and composition of calcareous sponge spicules: Are view and comparison to structurally related biominerals", Micron 39: 209-228.

[9] R. M. W. Van Soest, 1989, "The Indonesian sponge fauna : a Status Report", Netherlands Journal of Sea Research 23. 